\title{
U-PB ZIRCON CONSTRAINTS ON DEFORMATION AND INTRUSION, NORTHWEST ADIRONDACK HIGHLANDS AND ADJACENT ADIRONDACK LOWLANDS, NEW YORK
}
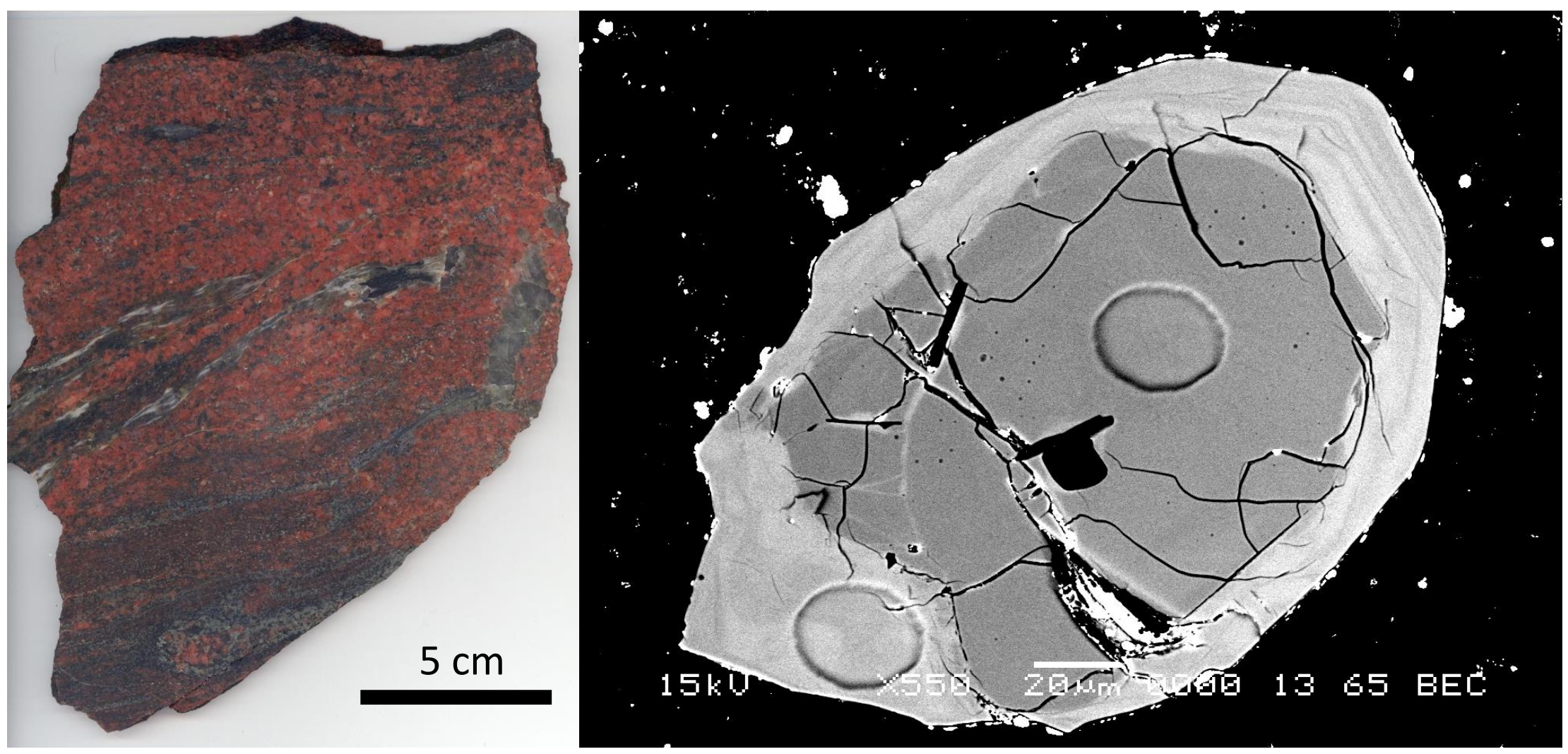

Bruce Selleck, Department of Geology, Colgate University Jeff Chiarenzelli, Department of Geology, St. Lawrence University James M. McLelland, Geology, Colgate University Marian Lupulescu, New York State Museum 
Megacrystic Gore Mountain-type garnets in the Adirondack Highlands: Age, origin, and tectonic implications

James M. Mclelland and Bruce W. Selleck*

$\boxplus$ Author Affiliations

د"bselleck@colgate.edu

Abstract

Spectacular exposures of the world's largest megacrystic garnets (to $35 \mathrm{~cm}$ years, numerous geologists have concluded that the large size of the garnets
resulted from an influx of fluds during ton 1050 ma mesulted from an influx of fluids during carphism of a ca 1155 s and close to, a steep border fault that
garnet ore at the southern margin of the veins are present in the border zone and $1 \mathrm{k}$ Ceochronology has played a critical role
Mountain aarnets. Over the past 20 vr $5 m$

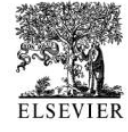
diameter) occur in a coarse-grained amphibolite at the Barton Garnet Mine in
the Adirondack Highlands (Gore Mountain, New York State, USA). Over the under such mid-crustal pressure-tempe
warrants explanation. Evidence indicates

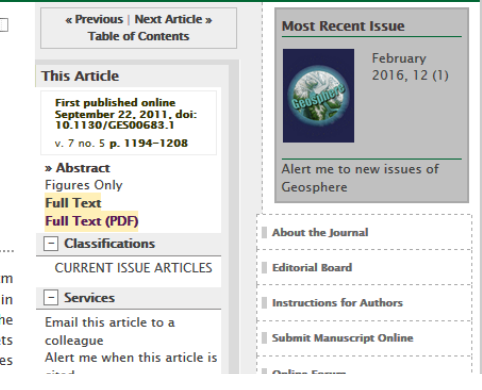

Precambrian Research 109 (2001) 39-72

\section{field guide: if you want to see the rocks}

Friends of the Grenville Field Trip 2005

The nature and significance of the Carthage-Colton Shear Zone and related late-to-post tectonic granites and ore deposits; Adirondack Mountains, New York

Leaders: Bruce Selleck, Department of Geology and Upstate Institute, Colgate University

Zircon U-Pb geochronology of the Ottawan Orogeny, Adirondack Highlands, New York: regional and tectonic implications

\section{stuff already James McLelland ${ }^{a, *}$, Michael Hamilton ${ }^{\mathrm{b}}$, Bruce Selleck published

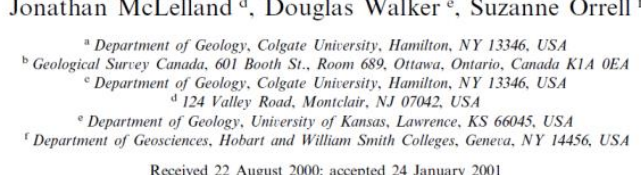 \\ Reccived 22 Augus 2000:- accepted 24 January 2001}

Eric Johnson, Department of Geology, Hartwick College

Granite emplacement during tectonic exhumation:

The Adirondack example

Geology, 2005

Bruce W. Selleck
Geology Department, Colgate University, 13 Oak Drive, Hamilton, New York 13346, USA

Geology Depantment, Colgate University, 13 Oak Drive,
James M. McLelland

Geosciences, Skidmore College, 815 North Broadway, S
M. E. Bickford

Earth Sciences, Syracuse University, 204 Heroy Geology Laboratory, Syracuse University, Syracuse, New York 13244-1070, USA

\section{ABSTRACT}

Sensitive high-resolution ion microprobe U-Pb zircon ages for late to posttectonic leucogranites fix the timing of extensional collapse of a portion of the Mesoproterozoic Gren
ville orogen of eastern North America. Plutons of Lyon Mountain Granite (LMG) were emplaced within the Carthage Colton shear zone svnchronously with formation of extensional mylonite at 1045-1037 Ma. Leucogranite melts were generated in the hot granulite facies core of the Adirondack Highlands-Central Granulite terrane that served as the lower plate for down-to-the-northwest extension. The LMG suite is associated with high temperature hydrothermal magnetite deposits in the Adirondack Highlands, and wide
spread $\mathrm{Cl}+\mathrm{CO}$, hydrothermal alteration of upper-plate rocks is localized along the Carthage Colton shear zone where IVG granites are present. The relationshipsong the melt generation, granite intrusion, high strain rates, extensional collapse, and hightemperature hydrothermal activity provide a framework for understanding midcrustal processes in modern and ancient orogenic belts.

Keywords: Grenville, zircon, geochronology, leucogranite, extension, mylonite.
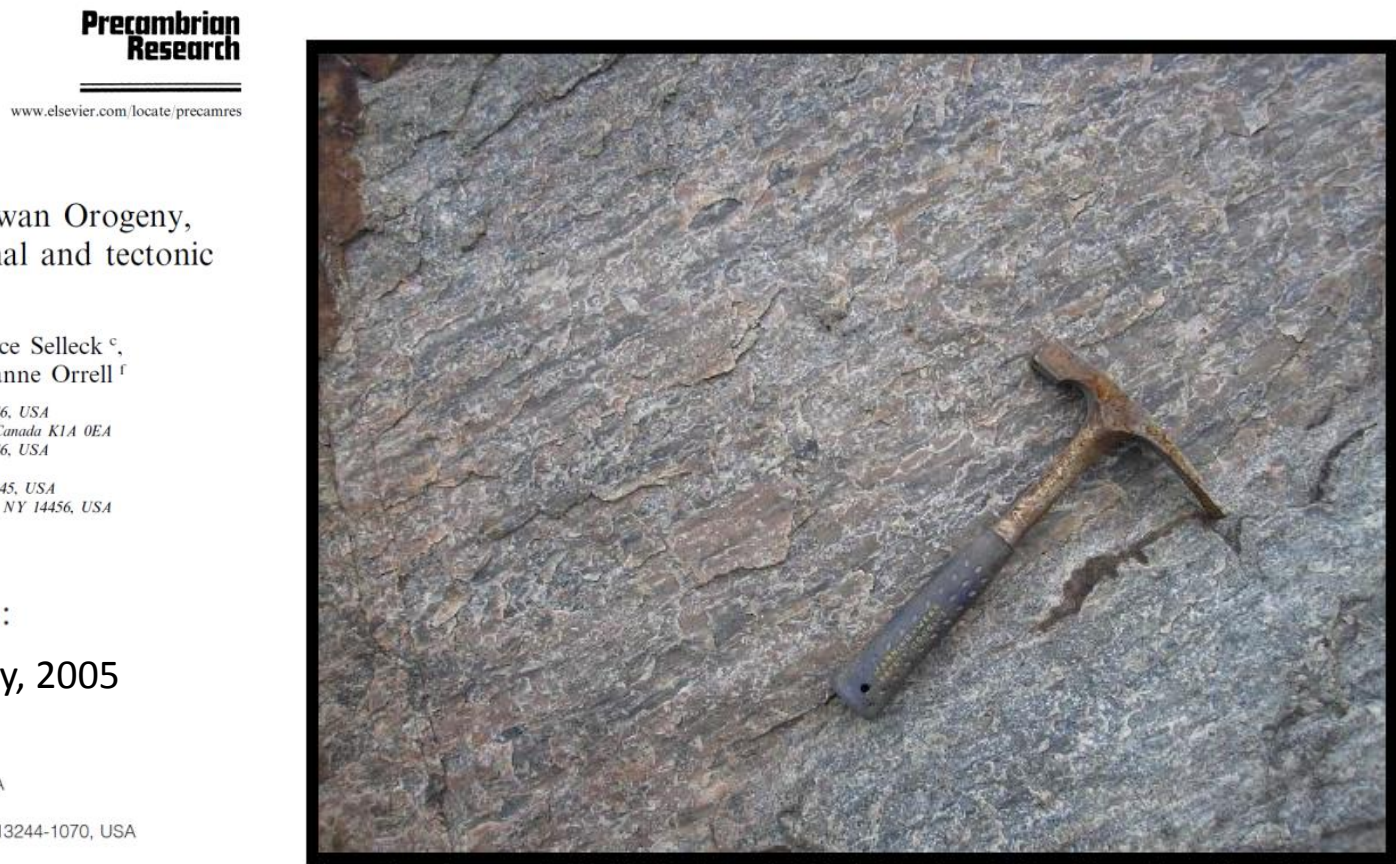

Diana Complex granitoid with l-s tectonite fabric, Carthage Colton Shear Zone, Fine, NY

Contributors:

Bill DeLorraine, Consulting Geologist

Marian Lupulescu, NYS Geol. Survey

new data: thanks to the Boyce Fund, Colgate University, Department of Geology 


\section{ADIRONDACK GEOLOGY/GEOCHRONOLOGY}

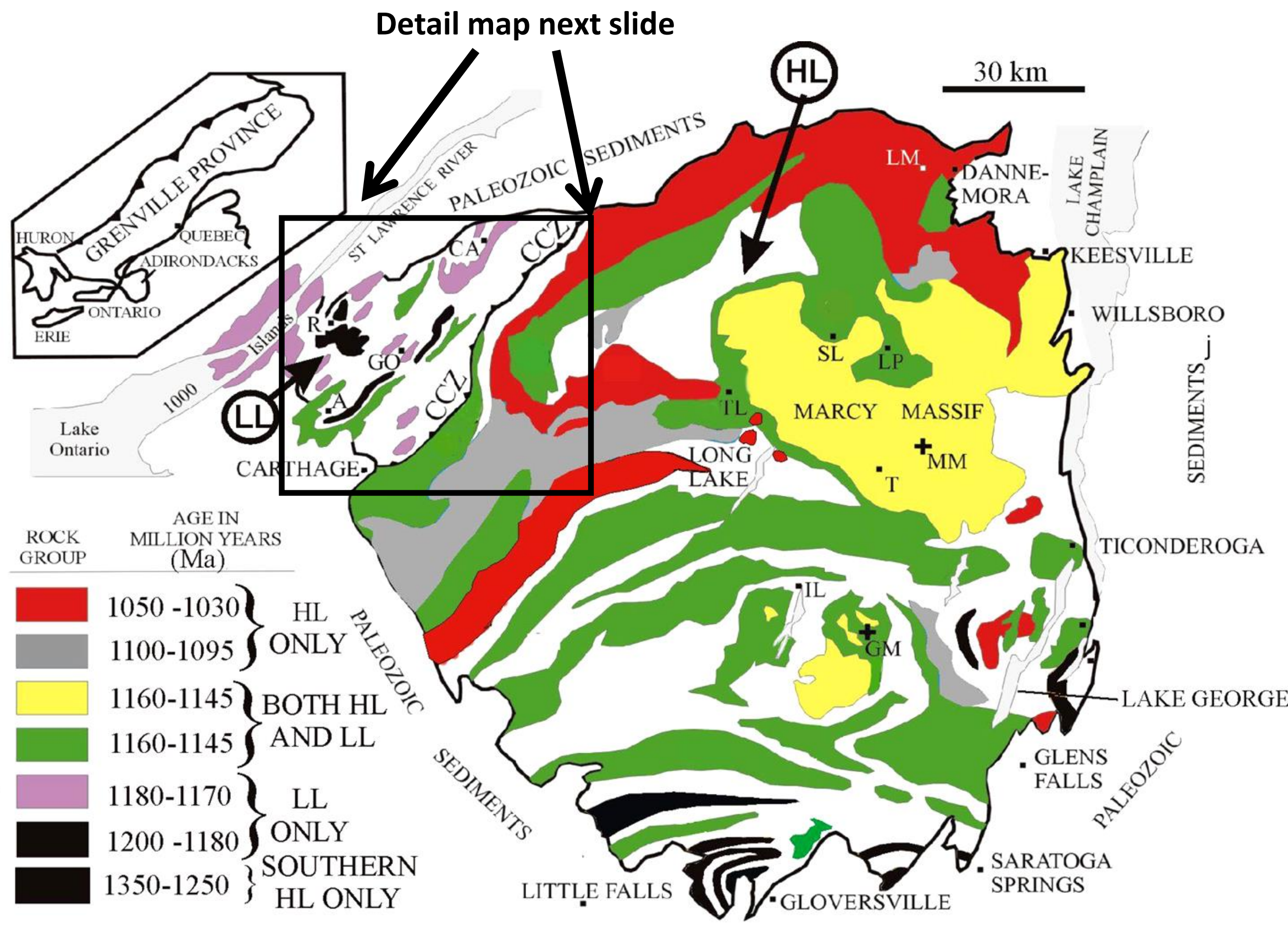




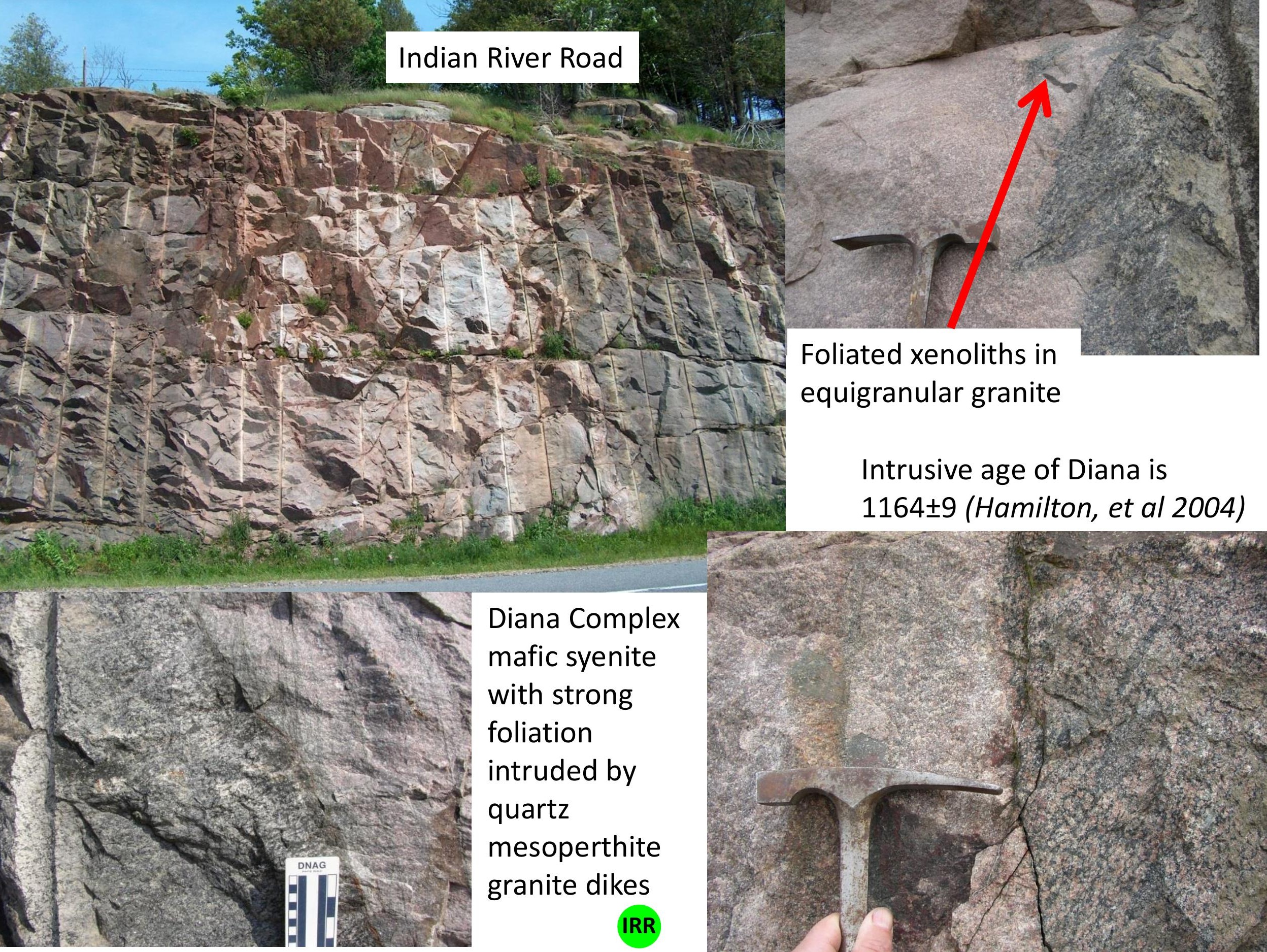


IRR leucogranite zircon SHRIMP

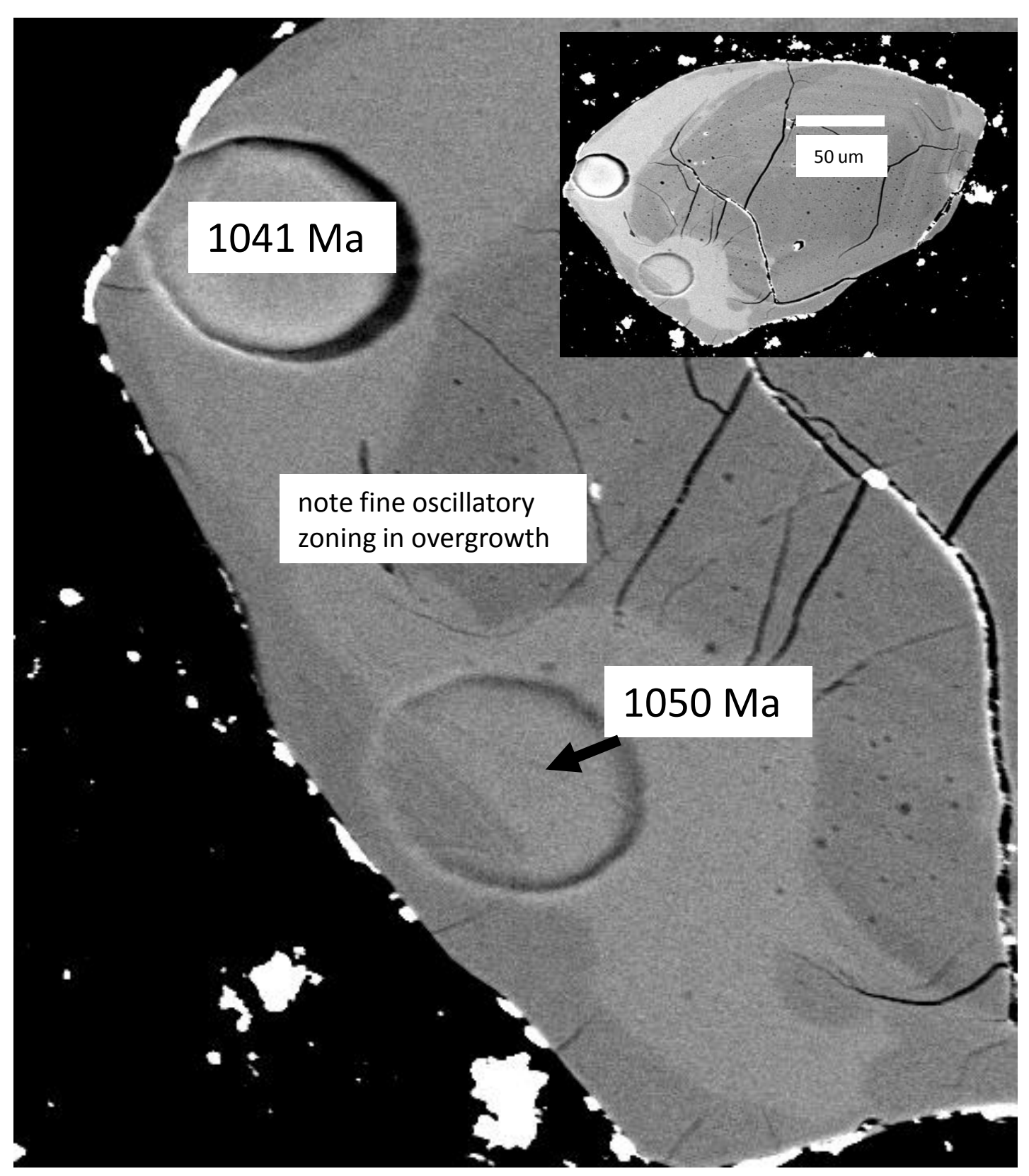
results (Selleck, et al 2005)

Zoned igneous overgrowths (leucogranite intrusive age)

Mean = $1039 \pm 10 \mathrm{Ma}$ [0.92\%] $95 \%$ conf.

MSWD $=0.63$, probability $=$ $0.68 ; \mathrm{n}=6$

Four xenocryst/core ages:

$1211 \pm 22$ Antwerp/Rossie $1202 \pm 11\}$ Suite? $1999 \pm 14$

1177ะ11] Diana Complex - host $1177 \pm 11\}$ mafic syenite

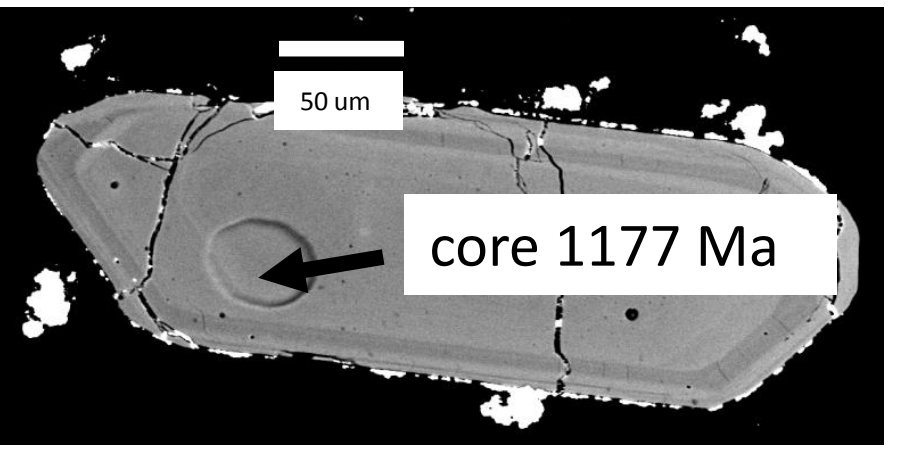


Brouses Corners - Carthage-Colton Zone

leucogranite sills intrude gneiss and calcsilicate

sills parallel strong mylonitic fabric

nearby leucogranite with quartz-sillimanite nodules and veins

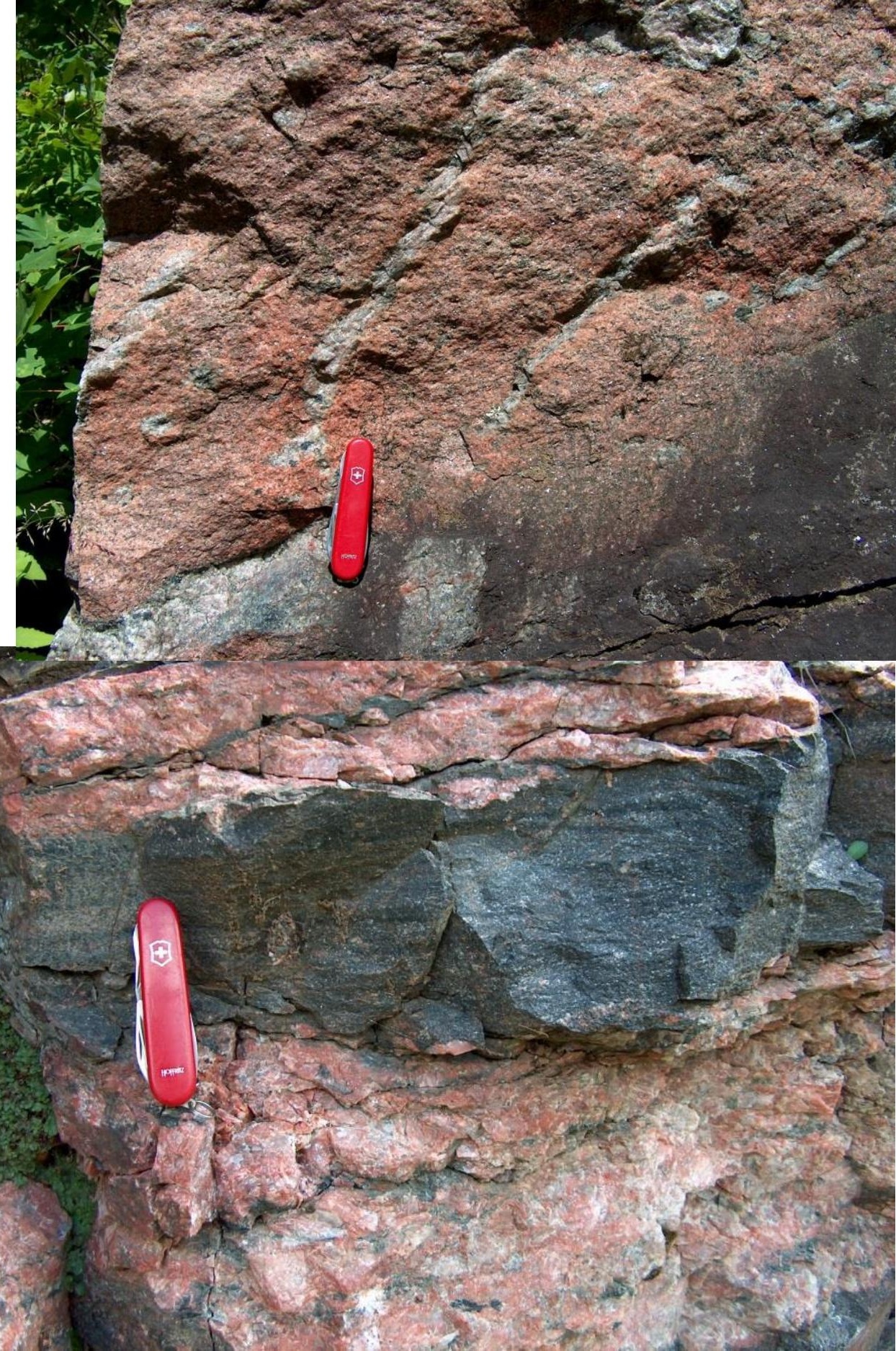


Brouses Corners (BC)

Granite pegmatite sills intrude NW dipping mylonitic gneiss. Strain indicators give consistent top-down to the NW shear sense.

Synmagmatic mylonite and ultramylonite suggest intrusion during rapid CCSZ extension.

Zircons from coarse granite pegmatite. granite pegmatite intrudes dark mylonite/ultramylonite but is itself mylonitized 


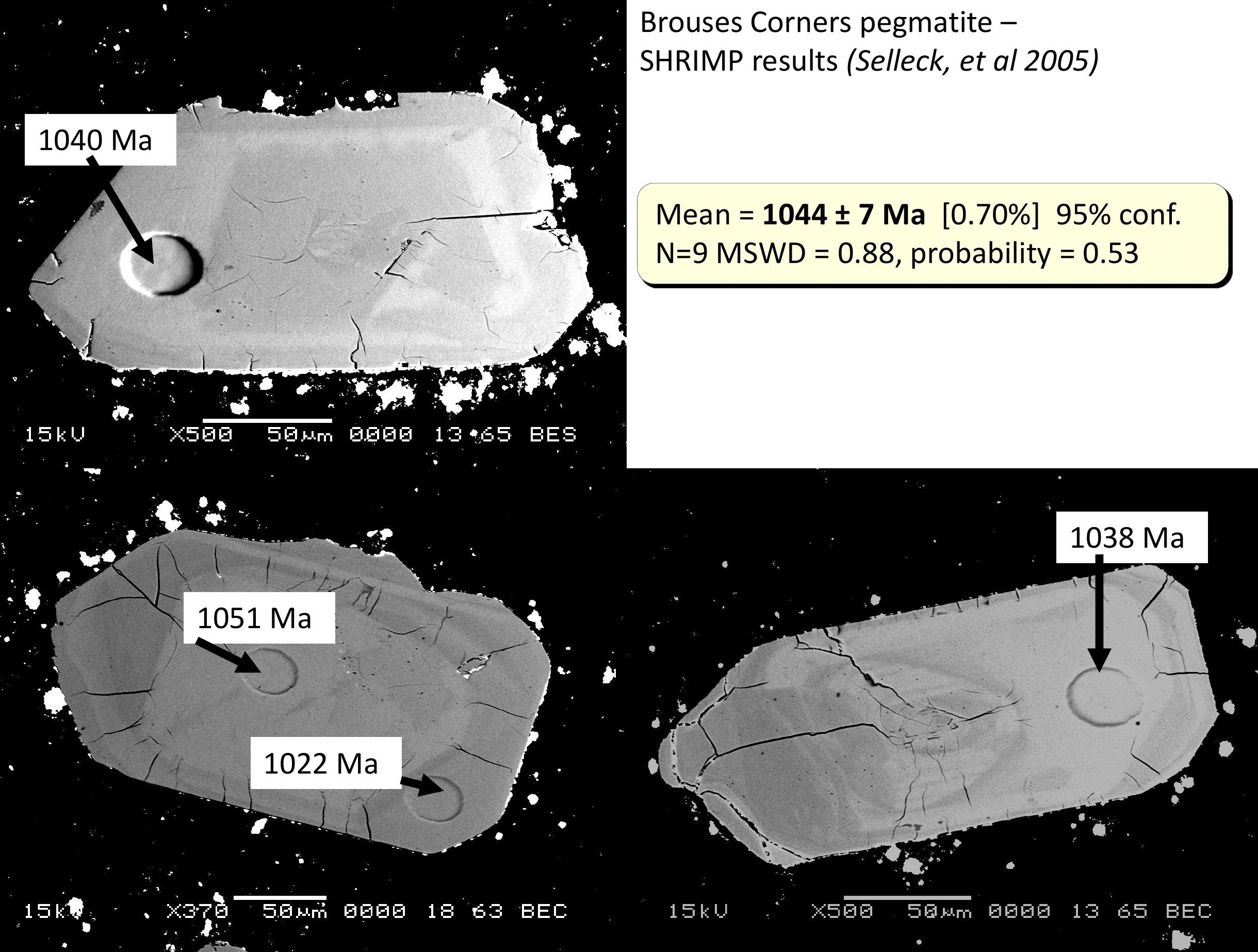




\section{The CL problem}

I ᄀ
B I EEEG WrGS

n븐

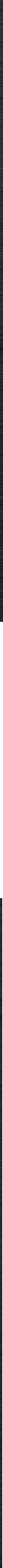




\section{Seveys Corners West}

\section{Pegmatite}

Final Age $=1044.2 \pm 8.6 \mathrm{Ma}$ Mean $=1044.2 \pm 1.9[0.18 \%] 2 \sigma$ Wtd by data-pt errs only, 0 of 20 rej. MSWD $=0.34$, probability $=0.996$

Pegmatite cross-cuts anatectic banding and foliation in leucosome-bearing amphibolite

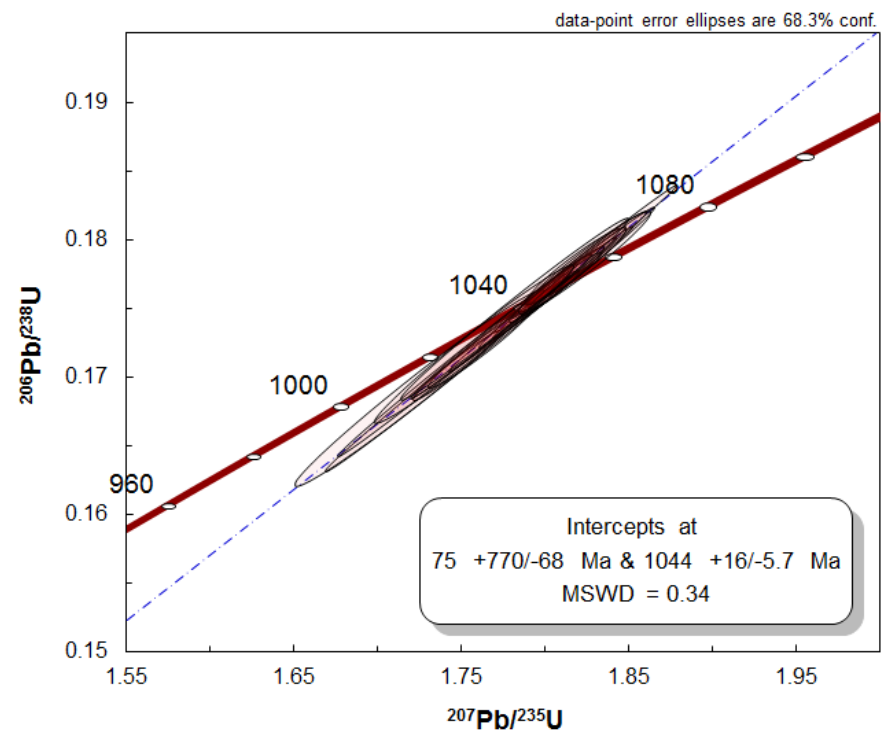

LA-ICPMS (Laserchron) data from here on

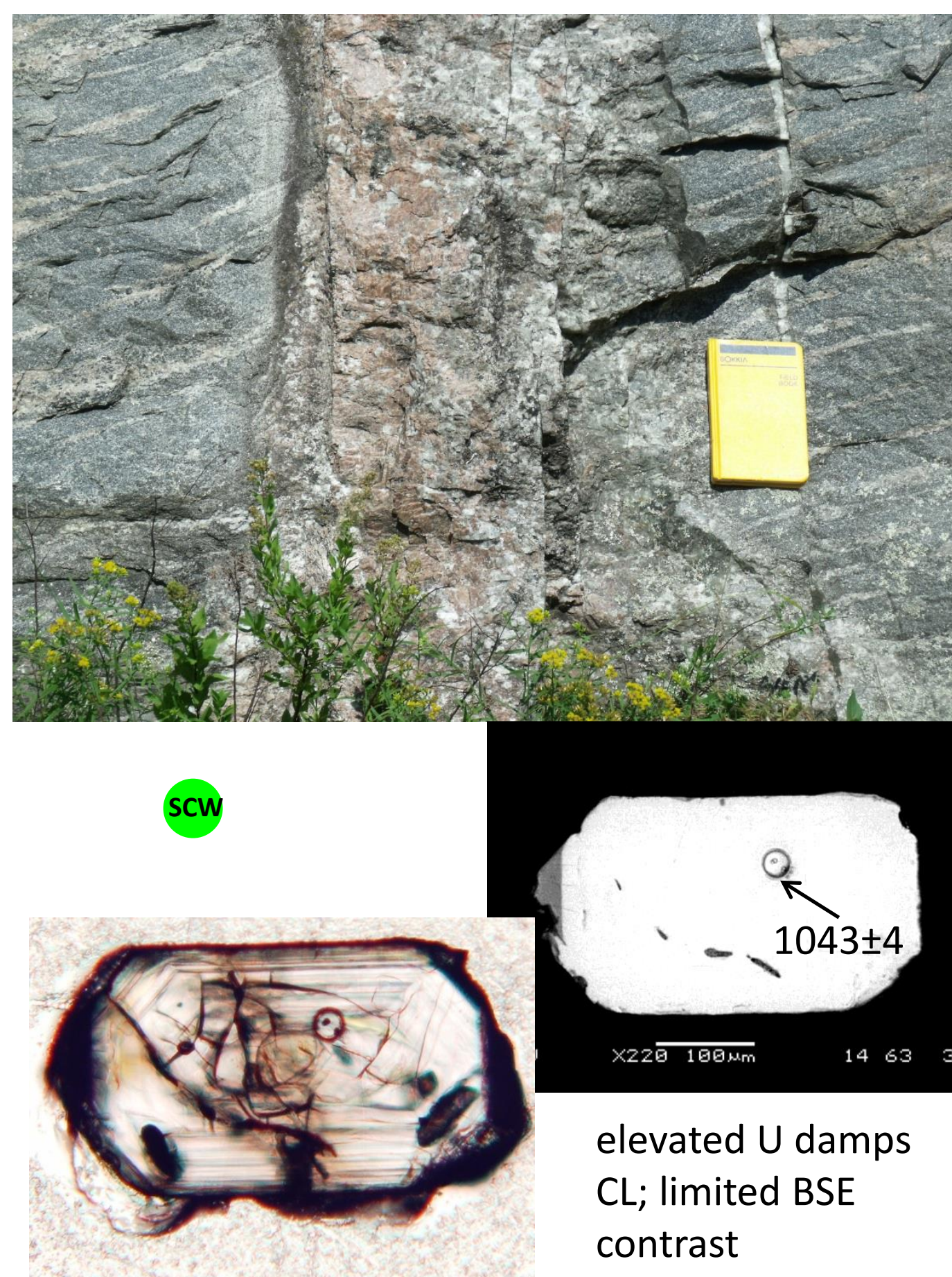


anatectite? sills parallel to foliation/banding in amphibolite pegmatite cross-cuts leucosome

leucosome $(1052 \pm 6) \approx$ pink granite $(1058 \pm 15) \approx$ amphibolite (1052 \pm 9)

pegmatite (1044 \pm 9$)$ - cross-cuts all

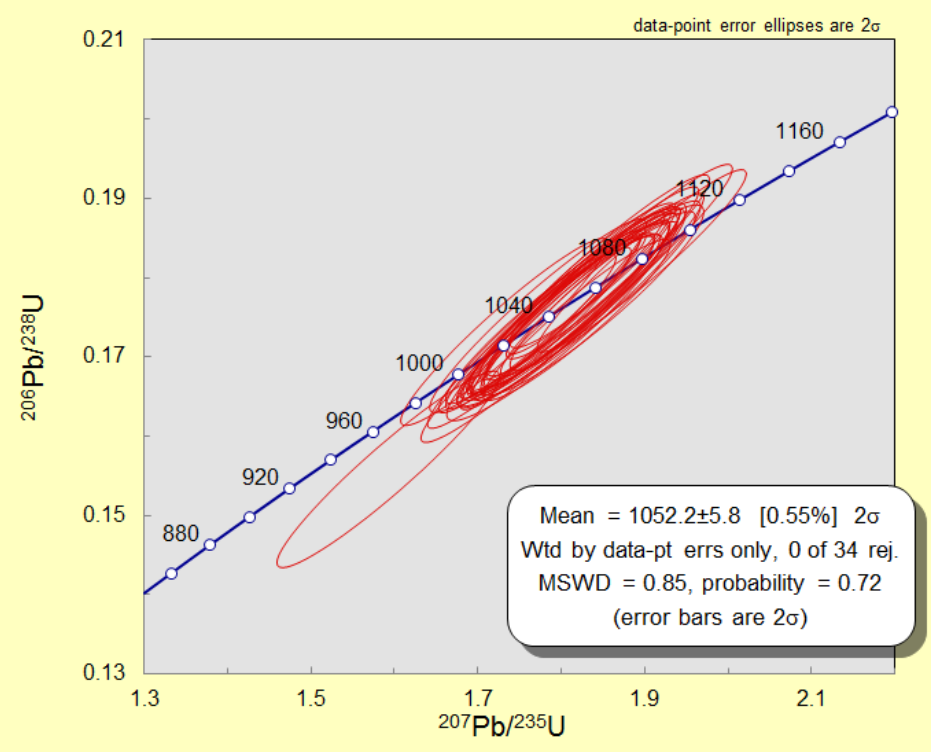

Leucosome/sills Mean $=1052.2 \pm 5.8[0.55 \%] 2 \sigma$ Wtd by data-pt errs only, 0 of 34 rej. MSWD $=0.85$, probability $=0.72$

\section{pegmatite}

leucosome/sills

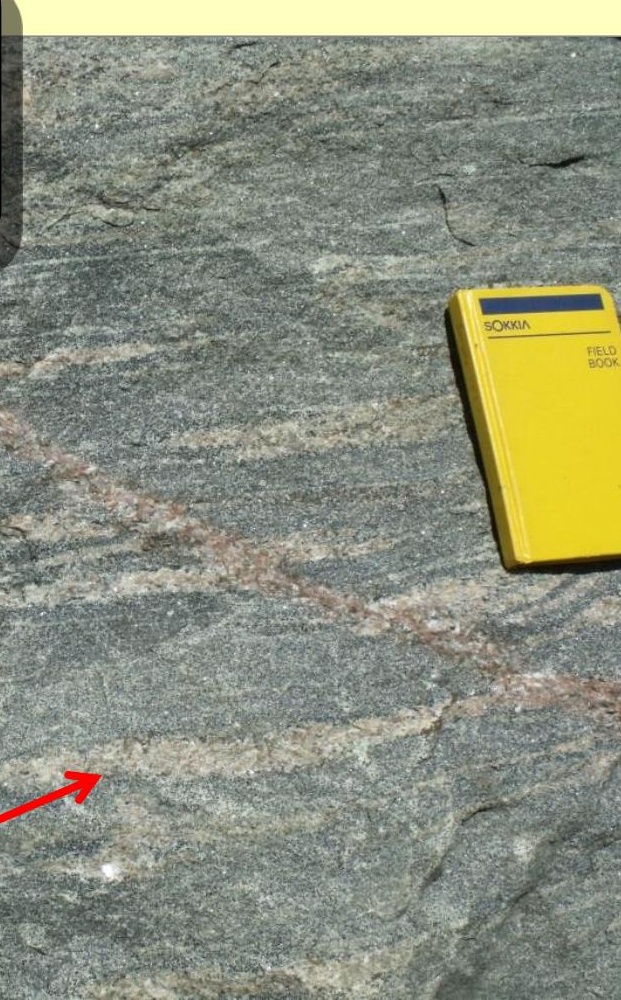


The U-Th problem

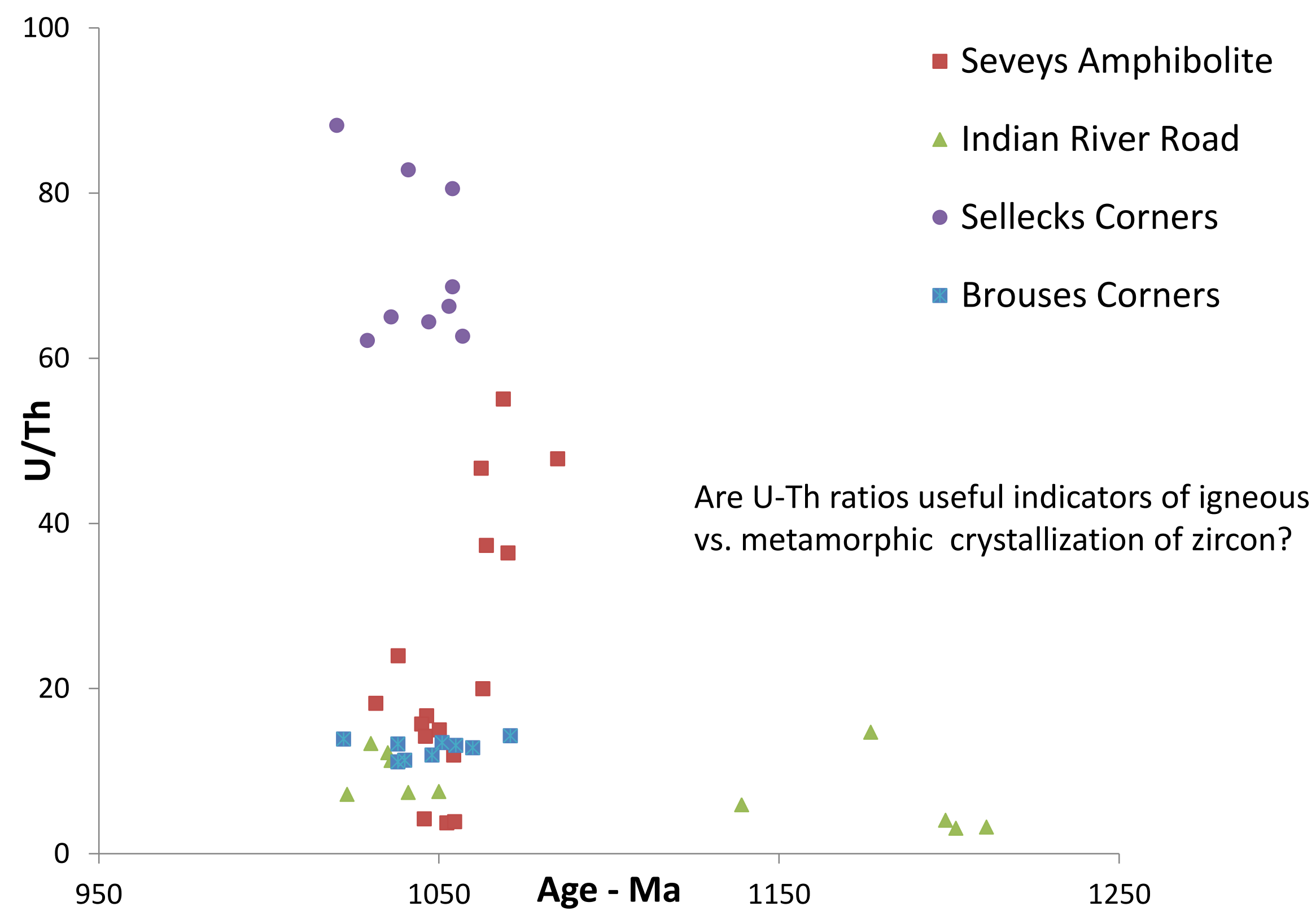




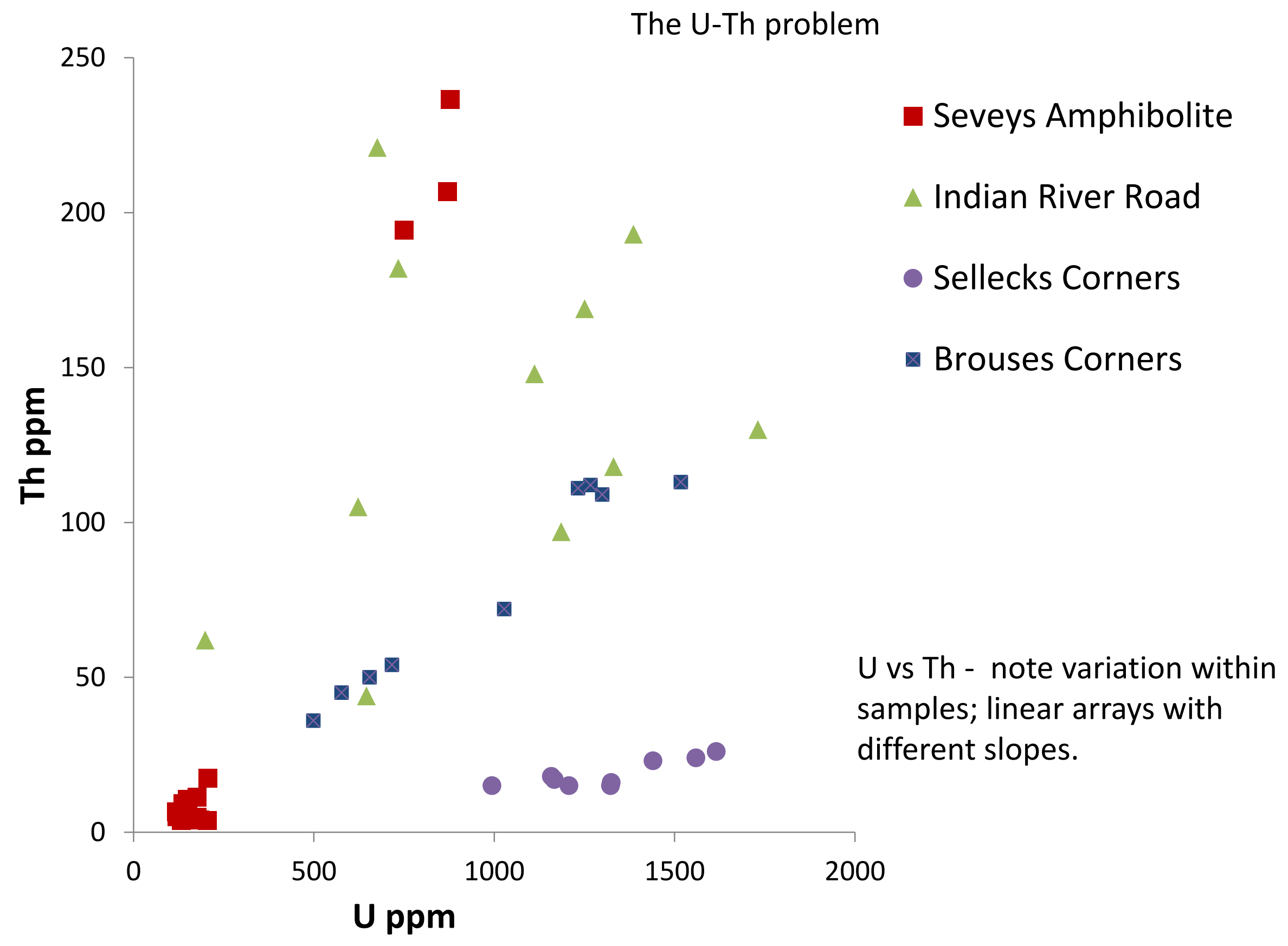


The U-Th problem

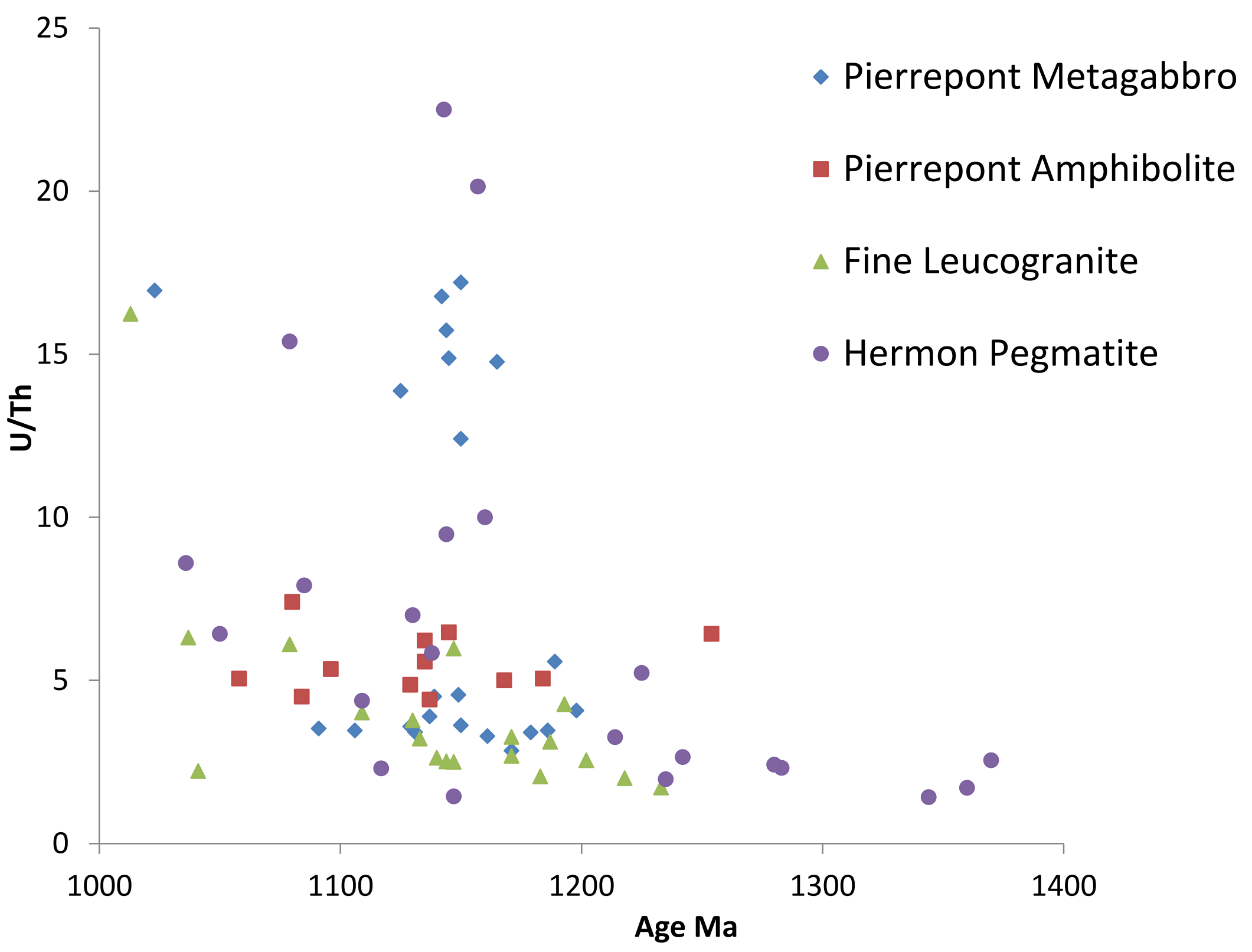




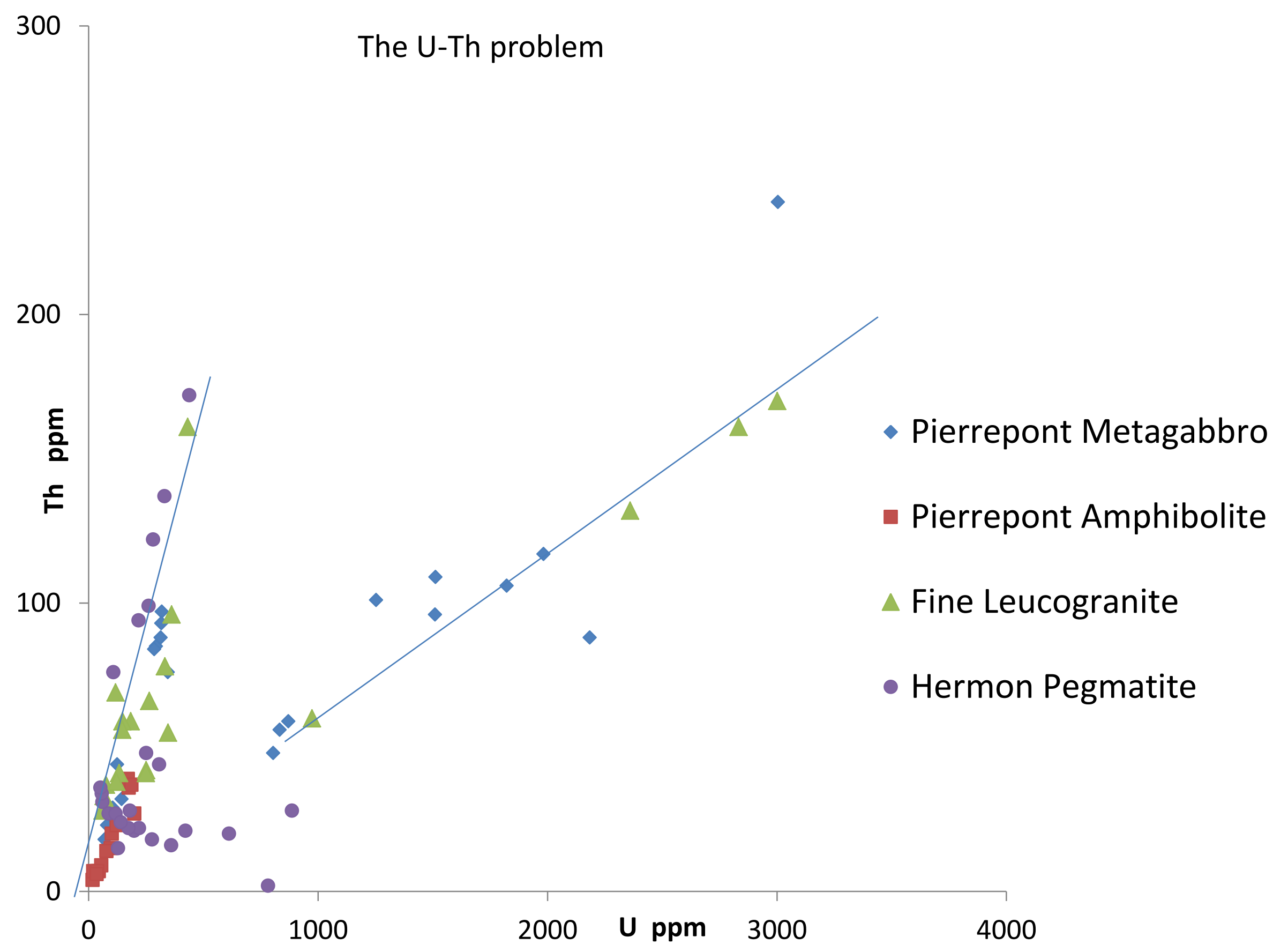

